\title{
Musical Cultures: To What Extent is the Language Used in the Song Lyrics of Hip-Hop and Country Music Reflective of and Shaped by Cultural Beliefs and Experiences?
}

\author{
Dwayne Engh ${ }^{1}$ \\ ${ }^{1}$ English Department, Tudor BEC College London, U.K. \\ Correspondence: Dwayne Engh (Received Masters in English Language Teaching and Applied Linguistics, King's \\ College London, 2010), St. Peter's Vicarage, 53 Belsize Square, London, U.K. E-mail: dwayneengh@shaw.ca
}

Received: August 31, 2013 Accepted: September 16, 2013 Online Published: September 23, 2013

doi:10.5539/ijel.v3n5p78

URL: http://dx.doi.org/10.5539/ijel.v3n5p78

\begin{abstract}
Hip-Hop and Country musicians concurrently create culture while being affected by the specific subculture of their sociolects and communities. Within these specific speech communities, language is a vital part of constructing reality; of showing class values; and of defining who is 'in' and who is not - often in terms of being in opposition to and standing apart from mainstream society. Inclusion in the Hip-Hop and Country subcultures indicates a delineating boundary of authenticity, which clearly suggests that there are others who are therefore not 'authentic' and must be excluded. Members view their group as separate and work to maintain the boundary from the other, from the majority. In the sociolinguistic exploration of Hip-Hop and Country communities, there are five major themes that will be considered: Legitimacy, Commodification \& Globalization, Boundary Margins, Sexuality, and Rebellion - giving prominence to the social context of language use rather than to purely lexical considerations within the two communities.
\end{abstract}

Keywords: music, hip-hop, country, authenticity, self-referential, sociolinguistic musical subcultures

\section{Introduction}

While recognising the distinctive approaches to organising language, cultural beliefs, and experiences in both the Hip-Hop and Country music communities, it is clear that there are multiple pragmatic universal commonalities.

Debate concerning linguistic relativity has been persistent since the Sapir-Whorf hypothesis was first proposed. Wierzbicka (1997, p. 5) argues for a strong version in stating, "it may seem obvious that words with special, culture-specific meanings reflect and pass on not only ways of living characteristic of a given society, but also ways of thinking," while Pinker, as a cognitive scientist, argues against any version of linguistic relativity, claiming "there is no scientific evidence that languages dramatically shape their speakers' ways of thinking" (1994, p. 48). Most involved in the scholarly debate, however, seem to take a more moderate view and agree "we dissect nature along lines laid down by our native languages" (Whorf, 1956, p. 213). Any person with an authentic cross-cultural experience could not deny that our world is, to some extent, mediated through language and that we attend to certain aspects of our world more than others because of the language we use.

If many researchers acknowledge at least moderate Whorfianism as true for languages of different cultural groups or nation-states, we may therefore argue that the same also holds true for sub-cultural groups and sociolects within wider society. Within these specific speech communities, language is a vital part of constructing reality; of showing class values; and of defining who is 'in' and who is not - often in terms of being in opposition to and standing apart from mainstream society.

\section{Methodology}

This qualitative study originated from a desire to explore the question: to what extent is the language used in the songs of Hip-Hop and Country music reflective of and/or shaped by cultural beliefs and experiences? A survey of relevant academic literature and representative musical examples of both Hip-Hop and Country communities were examined, relying to some extent on the researcher's background in linguistics and as a freelance musician. A taxonomy was developed to offer a preliminary framework for sociolinguistic commonalities and five major themes arose from the research. 


\section{Hip-Hop and Country Background}

Hip-Hop and Country musicians concurrently create culture while being affected by the specific subculture of their communities. Hip-Hop and Country are both musical styles and specific cultures - with their own language, ways of dressing, ways of being, ways of remembering and ways of creating identity. Country music, derived from a combination of Blues, Gospel and 'Old-Time music' from the Appalachian Mountains emerged from the American South at the beginning of the twentieth century, with the first recording being made in Atlanta, Georgia in 1923 by Fiddlin' John Carson (Peterson, 2013). The technology of the radio during the Depression helped spread the genre, the most important centre probably being the 'Grand Old Opry' in Nashville, which was broadcast weekly.

Alim $(2002,2004)$ differentiates the definition of the broader Hip-Hop Nation (HHN) culture from the linguistic musical activity of rap, which Alim defines as "the aesthetic placement of verbal rhymes over musical beats" (2004, p. 272). Hip-Hop started as an African-American urban expression in New York, derived from a long tradition of African musics in North America including Ragtime, Blues, Jazz, Gospel, Soul, and Rhythm \& Blues. While the Hip-Hop trio Sugar Hill recorded what most consider to be the first rap single, Rapper's Delight in 1979, the genre was not made popular until 'Yo! MTV Raps' went on air in 1989.

In the sociolinguistic exploration of Hip-Hop and Country communities, there are five major themes that will be explored:

- Legitimacy

- Commodification \& Globalization

- Boundary Margins

- Sexuality

- Rebellion

While there will be an attempt to examine each area separately, it is clear that there is much overlap between the different themes, all of which focus to some extent on the core issue of authenticity. Given the sociolinguistic focus of this paper, prominence will be given to the social context of language use rather than to purely lexical considerations within the two communities.

\section{Legitimacy - 'Keepin' It Real'}

Who can claim participation to a particular subculture and where is the boundary of who is 'in' and who is 'out'? To be true to one's roots and to not pretend to be something one is not is vitally important to both Hip-Hop and Country communities. Perhaps even more so is to not be too 'slick', implying an overly polished, superficial and untrustworthy demeanour (Cutler, 1999; Rickford and Rickford, 2000; Fox, 2004).

\subsection{Class \& Financial Challenges}

An important commonality is that both musics arose out of cultures that are predominantly blue-collar working class, with language being closely tied to financial stability and access to, or exclusion from, opportunity (Fitzpatrick, 2007; Fox, 2004). While frequent references to working class roots can be found in contemporary country artists, such as Toby Keith or Eric Church, it is quite explicitly stated in many songs such as Jonny Russell's Red Necks, White Socks, and Blue Ribbon Beer from 1973 with the lines, "No we don't fit in with that white-collar crowd, we're a little too rowdy and a little too loud."

There is also often an element of hardship and concern for simply surviving financially, as evidenced in the first line of Garth Brooks' 1993 song American Honky-Tonk Bar Association, "if your paycheck depends on the weather and the clock," or Tupac Shakur (2Pac)'s line, "tryin' to make a dollar outta 15 cents" from the 1993 I Get Around.

\subsection{Sense of Place}

Connected to the authenticity of 'Keepin' it real' is the sense of place. Hip-Hop is distinctly urban and continually connected to the reality of the black sociocultural context of the inner city 'street':

Legendary Hip Hop producer Marley Marl explains what it means to be "street-conscious": "I got to stay true to my people, you know what I'm saying? I stay true to Hip-Hop. I be in the streets, you know what I'm saying?" (Alim, 2002, p. 289)

Thus, the street as a physical location is "the center of hip-hop cultural activity," but also a "site of creativity, culture, cognition, and consciousness" (Cutler, 1999, p. 218 quoting Alim). The Message is one of many 
Hip-Hop charts that address some negative issues of the inner city 'street', comparing the street to the jungle thereby using the literal metaphor between jungle and street as well as possibly making connections to the African roots of the art form.

When white rapper Eminem entered the Hip-Hop scene, he had to work to counteract his race by appealing to his 'street cred' (credentials) with songs such as Yellow Brick Road, which expounds on his rough upbringing on the street:

On the east side of Detroit crossing 8 Mile into Warren, into hick territory... I am well aware that I don't belong here, you've made that perfectly clear, I get my ass kicked damn near everywhere. (Eminem, 2004)

While Hip-Hop focuses on the inner city street, Country is markedly anti-urban. It constructs a self-consciously 'country' or rural philosophy with positive connotations of the 'ordinary' and 'takin' it slow' as an expression of white working class in the American South. To be too urban, sophisticated or polished is to be 'slick' and therefore untrustworthy, someone or something that lacks authenticity. Tracy Byrd's I'm From the Country, addresses this authenticity with the line "down in the hollows where the folks are real," which leads to the end of the chorus:

We know how to work and we know how to play. We're from the country and we like it that way. (Byrd, 1998)

\subsection{Ethnicity}

Is 'keepin' it real' for the Hip-Hop community defined by ethnicity and living in the inner city, or is it the concept of being true to yourself? (Cutler, 1999a, 1999b; Pennycook 2003, 2007) Are White Hip-Hoppers in America, such as Eminem, or in the U.K., such as Plan B, inauthentic? Eminem addresses this in Yellow Brick Road, where there is recognition of the stereotype with the line "he looked at me like I'm out my mind, shook his head like white boys don't know how to rhyme."

In Sticky Fingaz's song What if I was White, his ironic exploration of racial stereotypes draws attention to perceived differences between the races:

If I was white, it would be a different world for me... (You'd probably live in a trailer park and be white trash)... But there's a good and a bad side to being white. You can't say the ' $\mathrm{N}$ word' without starting a fight, couldn't dance on beat - I'd have two left feet. (Sticky Fingaz and Eminem, 2001)

Many in the Country music community raise similar concerns of exclusively by ethnicity. "For, while country is definitely classed in complex ways, it is the 'pose' of whiteness that is among country music's most powerful obviousnesses" (Mann, 2008). Country artists, such as Charley Pride, stand out as an exception in a field of white artists and experienced similar challenges decades before Plan B or Eminem did the in the Hip-Hop community. American Honky-Tonk Bar Association delves into a playful exploration of self-identifying white stereotypes of 'redneck' or 'hick' while dealing with perceived country identity:

It represents the hardhat, gunrack, achin'-back... it represents the mud flaps, six pack, bare crack, over-taxed, flag-wavin', fun-lovin' crowd. (Brooks, 1993)

Mann goes on to argue that "the nostalgia that suffuses country music might be plainly white," which would be less likely to appeal to non-white listeners in that it harkens back to a time in American history before Brown vs. Board of Education and the Civil Rights Movement.

\section{Commodification \& Globalization}

The claim of authenticity is a critical issue in tension with commodification and globalization of the musics in both Country and Hip-Hop musical communities.

\subsection{Commodification}

When approaching the concept of commodification, we must ask who the intended audience is, who are the unseen interlocutors in the conversation? For Hip-Hop, the lyrics are targeted to and intentionally written as if speaking to inner city African-American street culture (Bell, 1984; Alim, 2002) and for Country, the rural white working class. In tension with this is the recognition from both musical communities that the majority of their music sales are to white upper middle class suburbanites. For this reason, Fox argues it is impossible to locate an 'authentic' country song in post-modern capitalist society. "Country resists all such attempts; it incorporates and combines the true and the false into a poetic which is explicitly deconstructive of the ideology which these categories encode" (Fox, 1992, p. 53). The inherent contradiction is that there continues to be an elusive 
authenticity both musically and linguistically along with a "tense interplay between subcultures and their (virtually instant) commodification" (Potter, 1995, p. 131).

There is an awareness of the contradictions of being real and appealing to a wider audience in order to sell their music, even if that wider audience is the inauthentic 'urban cowboy' (a city dweller who pretends to be a cowboy from the country) or the 'wigger' (a white suburbanite striving to participate in African-American street culture). The crossover band M.O.D. explored this theme of white suburbanite youth pretending to be black with Wigga:

Hey white boy, can't you find the beat? You ain't street, you're trippin' on your own feet... wigga, wigga - white boy; wigga, wigga, gangsta wanna-be. (M.O.D., 2003)

\subsection{Globalization}

What then is the definition of being authentic? Are artists of the Global Hip-Hop Community such as Nederhop in the Netherlands, Canada's 'Hick-Hop' artist Ridley Bent or Japanese Hip-Hoppers centred around the 'Nip-Hop' website included? "If Japanese hip-hop has its own culture, is this global hip-hop with a Japanese flavour, Japanese culture with a global orientation, or something new altogether?" (Pennycook, 2007, p. 5). The same questions can be asked of the somewhat more limited, but still global, Country music scene. Are artists from Australia, Britain or Mexico still authentic Country musicians? I would suggest Country artists such as Toby Keith with his song Courtesy of the Red, White and Blue (The Angry American) (2002), including patriotic lyrics such as "ccause we'll put a boot up your ass, it's the American way" are among songs that work to exclude both artists and listeners outside of the United States. Are these other global artists then merely appropriating musically and linguistically, or are they creating fresh expressions and transcultural flows as Pennycook (2007) contends?

\section{Boundary Margins - Identity by Exclusion}

The inclusion in the Hip-Hop and Country subcultures indicate a delineating boundary, which clearly suggests that there are others who must be excluded. Members view their group as separate and work to maintain the boundary from the other, from the majority. Ibrahim (1999) suggests that a person invests where they see themselves mirrored. This investment and boundary maintenance includes both linguistic and cultural behavioural patterns.

\subsection{Language}

One clear way that this boundary can be maintained is by language. Hip-Hop and Country artists are very aware of their language and self-consciously construct their lexical production when performing, often changing their speech to build solidarity with their intended interlocutor and to exclude those not members of the group (Bell, 1984; Cutler, 1999b; Alim, 2004). An example of this linguistic self-awareness is Nelly's Country Grammar (2000) with the lyrics "My grammar be's Ebonics, gin tonic and chronic, F--- bionic it's ironic..."

Rickford and Rickford maintain that:

slick lexicon is hip-hop's Magna Carta, establishing the rights of its disciples to speak loudly but privately, to tell America about herself in a language that leaves her puzzled. (2000, p. 86)

Choices of diction and inflection are as important as lexical choices in Hip-Hop or Country. In fact, although classified as country simply because of the distinctive southern drawl, Goddu $(1998$, p. 47) argues that many popular newer country artists such as Faith Hill, Shania Twain or Tim McGraw are indistinguishable musically from many soft-rock records in the Top 40. The voiced southern drawl, with the deliberate creation of a consistent diphthong is a key factor to authenticity and identification of country music. "Twang - lyrical and/or musical - is thus self-referential in country music, it avers a song's authenticity like a badge or bumper sticker" (Mann, 2008, p. 79)

\subsection{Tradition}

A sense of history and self-referential connection to the past is another way that boundaries are reinforced and maintained. Smitherman contends that the rap music artist is rooted in Black oral tradition, essentially "a postmodern African griot, the verbally gifted storyteller and cultural historian" (1997, p. 4), thereby connecting Hip-Hop to the societies of ancient Egypt and West Africa with a reverence for spoken rhetoric (Kopano, 2002). In the same way, Country artists have been compared to the equivalent Western European model of the troubadour. The song Troubadour looks back to make a number of connections:

Sometimes I feel like Jesse James, still tryin' to make a name, knowing; nothing's gonna change what I am. I was a young troubadour when I rode in on a song and I'll be an old troubadour when I'm gone. (Strait, 2008) 
Besides the connections Strait makes to the troubadour poet musician of the Middle Ages, the lyrics look back to outlaw cowboy Jesse James, a possible metaphor not only for a celebrity of the Wild West but also of the Confederacy of the American Civil War. This is an interesting connection, as a number of Country scholars have suggested that the white working class origins of the Country music subculture have origins in and still identify with the ideals (and potential prejudices) of the Confederacy (MacKay, 1993; Fox, 2004; Mann, 2008).

\subsection{Self Reference}

Also interesting to note is the history of self-reference in both the Hip-Hop and Country communities, constantly making comments on its own authenticity.

\subsubsection{Individual Song Level}

Brad Paisley's title track This is Country Music is an excellent example of country's self-referential manner with lyrics such as:

So turn it on, turn it up and sing along. This is real. This is your life in a song. Yeah, this is country music.

Paisely attempts to claim a status as champion of traditional country within a contemporary country music framework. In a similar manner, there are numerous examples of MCs arguing they are the premier qualified upholders of rap and Hip-Hop in battles between MCs, as well as in commercially popular tracks.

\subsubsection{The Artist's Life}

Referencing also occurs within the public presentation of the artist's life and life experiences. In Hip-Hop, many artists attempt to portray a rough criminal or ex-con street exterior, with many popular MCs having been charged or jailed without affecting, perhaps even increasing, album sales. This also occurs within country music:

...it is not enough to perform, write, or produce country music, one must authenticate one's own life experiences. Autobiography in a variety of forms is pervasive in country music. Despite the artifice of the genre and its show business roots in vaudeville and the traveling medicine show, 'real' cowboys, cons, and coal miners' daughters abound. (Williams and Morrisey, 2000, p. 162)

\subsubsection{Within the Genre}

There is a strong tradition of self-referential sampling of previous artist's work in Hip-Hop culture, with samples being lifted from a variety of places including Funk and R\&B. These samples act as cultural markers, with the intention of inviting the listener into an active intertextual collective memory of the past and to consider how that connects to the present (Rose, 1991). The same sense of living memory is also present in Country music. The Hobbs song Jones on the Jukebox uses the metaphor of the jukebox to introduce melodic and textual fragments from earlier Country pieces into the current narrative. The intertextual linguistic references to famous country singer George Jones are present throughout the song, as are playful hints at the financial aspect of the jukebox to a performer. "The poetic use of the 'jukebox' in country music inverts this archetypal example of alienation, commodity fetishism, and the loss of history, into a historically self-conscious assertion of control over the process of mediation" (Fox, 1992, p. 62)

\section{Sexuality - Heterosexual Normative and Sexism}

An element of the polarisation created with 'us-them' boundary language extends to the 'male-female' dichotomy and heteronormativity of both Hip-Hop and Country music. In making this claim, I extend Stephens' (2005) argument that Eminem's repeatedly discriminatory and anti-gay behaviour is more appropriately considered a genderphobia instead of homophobia, therefore concerned with stereotypical gender performability (Cameron, 2010) of many Country and Hip-Hop artists.

She Thinks My Tractor's Sexy lyrics reinforces traditional sex roles and heteronormativity, which comes from a Country artist who appears to self-consciously portray the image of the 'ladies' man' in order to sell music:

Plowing these fields in the hot summer sun, over by the gate - lordy, here she comes with a basket full of chicken and a big cold jug of sweet tea... She thinks my tractor's sexy, it really turns her on. (Chesney, 1999)

Thankfully, there has been recent support for openly LGBT artists in both Country and Hip-Hop genres. Artists such as Angel Haze, Brooke Candy, Last Offence and Tori Fixx (identified with 'homo-hop' group Rainbow Flava) are all working to counteract heteronormative values within the Hip-Hop industry. In the Country genre, contemporary artists like Chely White, Steve Grand, k.d. lang or Doug Stevens \& the Outband are also starting to break down prejudices and norms. 
There are also numerous examples from both genres that display blatantly sexist themes. Examples of the objectification of women are found in the Hip-Hop tune Area Codes:

I got ho's in different area codes... Globe-trot international postman, neighbour-dick dopeman. (Ludacris and Nate Dogg, 2001)

as well as Country music's Tight Fittin' Jeans:

In my mind she's still a lady, that's all I'm gonna say... I "knew" a lady wearin' tight fittin' jeans. (Twitty, 1981)

In contrast, there are strong female Hip-Hop and Country artists battling with those stereotypes, such as Queen Latifah's chart U.N.I.T.Y.:

Every time I hear a brother call a girl a bitch or a ho, trying to make a sister feel low - you know all of that gots to go. (Latifah, 1993)

or Country artist Reba McEntire's I'm a Survivor:

A single mom who works two jobs, who loves her kids and never stops. With gentle hands and the heart

of a fighter, I'm a survivor. (McEntire, 2001)

\section{Rebellion - Critique of Reality}

\subsection{Anti-Establishment Critique}

The last theme to be examined is the anti-establishment critique present in much of the music of both the Hip-Hop and Country communities. Reed's She Got the Goldmine and I Got the Shaft delves into divorce, not aiming his anger at the spouse, but instead aiming a critique at the injustices that a powerless, undereducated working-class man experiences at the hands of the legal system (Lewis, 1993).

She got the goldmine, I got the shaft. They split it right down the middle, and they gave her the better half... I'm gonna be carryin' food stamps, you get it, judge? ... that's not funny, huh? Contempt of court, what do you mean contempt of court? (Reed, 1982)

\subsection{Critical Testimony}

However, within the articulate critical testimony and social protest is also the potential for transformation and hope (hooks, 1991).

Thus rap music is not only a Black expressive cultural phenomenon; it is, at the same time, a resisting discourse, a set of communicative practices that constitute a text of resistance against White America's racism and its Eurocentric cultural dominance. (Smitherman, 1997)

This emancipatory nature can be seen in 2Pac's lyrics from Me Against the World:

Through this suppression they punish the people that's askin' questions. And those that possess steal from the ones without possessions. The message I stress: to make it stop, study your lessons. Don't settle for less - even the genius asks-es questions. (2Pac and Dramacydal, 1995)

Music has also been a force to challenge racism and prejudice. Merle Haggard's Irma Jackson is one early example in Country music 'which highlight and challenge forces of domination and exclusion in contemporary society' (Mann, 2008, p. 77).

\subsection{Violence \& Battling}

Of course, one expression of rebellion is through violence, although Rose (1991) argues against this social construction of violence and how particular acts are defined as violent, especially when comparing aggressive behaviour in white communities with black communities in America. God Bless the Dead explores this issue:

God bless the dead \& buried n-gga. Don't worry if you see God first, tell Him shit got worse... See I'm old enough to know that ain't not justice. F--- the police and all the courts same way they f---ed us, and why the hell am I locked in jail, they let them white boys free. (2Pac and Stretch, 1994)

Aggressiveness continues in rap music itself through 'battling', a competition between two MCs with the aim to dominate and humiliate the opponent with quick wits and linguistic skills. This violent "discourse is intended to negotiate respect and social status, while simultaneously functioning as a creative outlet for verbal art and craftsmanship" (Fitzpatrick, 2007, p. 64). Never Enough states:

You go say the wrong shit and get your face split. The smell of victory, love it so much I can taste it. I spot my target, blaze it, direct hit... No matter how many battles I been in and won... no matter how 
many MCs I eat up, ooh, it's never enough... (Eminem, Nate Dogg and 50 Cent, 2004)

\section{Conclusion}

In summary, the writer recognises that this brief overview may have raised more questions than it has adequately answered. However, the intention was not to conclusively answer questions, but to suggest from a sociolinguistic perspective that the language choices in the music of Hip-Hop and Country communities are both reflective of and affected by the cultural beliefs and experiences of those specific subcultures. By exploring the themes of legitimacy, commodification, boundary margins, sexuality and rebellion, this writer has suggested that language is a vital part of constructing reality and identity within these specific communities. Interestingly, while clearly being expressed with different linguistic choices there are more commonalities between the two communities than might be expected. Hopefully, the artists of both communities will persist in the creation and recreation of that reality through their linguistic choices so that more empirical and comparative research can occur in the future.

\section{References}

Alim, H. S. (2002). Street-Conscious Copula Variation in the Hip Hop Nation. American Speech, 77(3), 288-304. http://dx.doi.org/10.1215/00031283-77-3-288

Alim, H. S. (2004). Hip Hop Nation Language. In A. Duranti (Ed.), Linguistic Anthropology: A Reader (2nd ed., pp. 272-289). Cambridge: Cambridge University Press.

Bell, A. (1984). Language Style as audience design. Language in Society, 13(2), 145-204. http://dx.doi.org/10.1017/S004740450001037X

Cameron, D. (2010). Sex/Gender, Language and the New Biologism. Applied Linguistics, 31(2), 173-192. http://dx.doi.org/10.1093/applin/amp022

Cutler, C. (1999a). “Keepin' it Real”: White Hip-Hoppers' Discourses of Language, Race and Authenticity. Journal of Linguistic Anthropology, 13(2), 211-233. http://dx.doi.org/10.1525/jlin.2003.13.2.211

Cutler, C. (1999b). Yorkville Crossing: White teens, Hip Hop and African American Language. Journal of Sociolinguistics, 3(4), 428-442. http://dx.doi.org/10.1111/1467-9481.00089

Fitzpatrick, J. (2007). Analyzing Hip Hop Discourse as a Locus of 'Men's Language'. Texas Linguistics Forum, 51, 64-73.

Fox, A. (1992). The Jukebox of History: Narratives of Loss and Desire in the Discourse of Country Music. Popular Music, 11(1), 53-72. http://dx.doi.org/10.1017/S0261143000004840

Fox, A. (1993). Split Subjectivity in Country Music and Honky-Tonk Discourse. In G. Lewis (Ed.), All that Glitters: Country Music in America (pp. 131-139). U.S.A.: Bowling Green State University Popular Press.

Fox, A. (2004). Real Country: Music and Language in Working-Class Culture. U.S.A.: Duke University Press.

Goddu, T. (1998). Bloody daggers and lonesome graveyards: The gothic and country music. In C. Tichi (Ed.), Reading Country Music: Steel Guitars, Opry Stars, and Honky-Tonk Bars (pp. 45-64). North Carolina: Duke University Press.

Hooks, B. (1990). Yearning: Race, Gender and Cultural Politics. Boston: South End.

Ibrahim, A. (1999). Becoming Black: Rap and Hip-Hop, Race, Gender, Identity, and the Politics of ESL Learning. TESOL Quarterly, 33(3), 349-369. http://dx.doi.org/10.2307/3587669

Kay, P., \& Kempton, W. (1984). What Is the Sapir-Whorf Hypothesis? American Anthropologist, 86(1), 65-79. http://dx.doi.org/10.1525/aa.1984.86.1.02a00050

Kiesling, S. (2005). Homosocial desire in men's talk: Balancing and re-creating cultural discourses of masculinity. Language in Society, 34, 695-726. http://dx.doi.org/10.1017/S0047404505050268

Kopano, B. (2002). Rap music as an extension of the black rhetorical traditional: "Keepin' it real." Western Journal of Black Studies, 26, 204-214.

Lewis, G. (Ed.) (1993). All that Glitters: Country Music in America. U.S.A.: Bowling Green State University Popular Press.

Mackay, J. (1993). Populist Ideology and Country Music. In G. Lewis (Ed.), All that Glitters: Country Music in America (pp. 285-316). U.S.A.: Bowling Green State University Popular Press.

Mann, G. (2008). Why does country music sound white? Race and the voice of nostalgia. Ethnic and Racial 
Studies, 31(1), 63-100. http://dx.doi.org/10.1080/01419870701538893

Niemeir, S., \& Dirven, R. (Eds.). (2000). Evidence for Linguistic Relativity. Amsterdam: John Benjamins Publishing.

Pennycook, A. (2003). Global Englishes, Rip Slyme, and performativity. Journal of Sociolinguistics, 7(4), 513-533. http://dx.doi.org/10.1111/j.1467-9841.2003.00240.x

Pennycook, A. (2007). Global Englishes and Transcultural Flows. New York: Routledge.

Peterson, R. (2013). Creating Country Music: Fabricating Authenticity. Chicago: University of Chicago Press.

Pinker, S. (1994). The Language Instinct. New York: HarperCollins.

Potter, R. (1995). Spectacular Vernaculars: Hip-Hop and the Politics of Postmodernism. New York: State University of New York Press.

Rickford, J., \& Rickford, R. (2000). Spoken Soul: The Story of Black English. U.S.A.: Wiley \& Sons.

Rose, T. (1991). "Fear of a Black Planet": Rap Music and Black Cultural Politics in the 1990s. The Journal of Negro Education, 60(3), 276-290. http://dx.doi.org/10.2307/2295482

Rose, T. (1994). Black Noise: Rap Music and Black Culture in Contemporary America. Middleton, CT: Wesleyan University Press.

Smitherman, G. (1997). "The Chain Remain the Same": Communicative Practices in the Hip Hop Nation. Journal of Black Studies, 28(1), 3-25.

Stephens, V. (2005). Pop goes the rapper: A close reading of Eminem's genderphobia. Popular Music, 24(1), 21-36. http://dx.doi.org/10.1017/S0261143004000261

Whorf, B. (Carroll, J., Ed.). (1956). Language, Thought, and Reality: Selected Writings. U.S.A.: Massachusetts Institute of Technology.

Wierzbicka, A. (1997). Understanding Cultures Through Their Key Words: English, Russian, Polish, German, and Japanese. New York: Oxford University Press.

Williams, M., \& Morrisey, L. (2000). Constructions of Tradition: Vernacular Architecture, Country Music and Auto-Ethnography. In S. McMurry, \& A. Adams (Eds.), People, Power, Places. U.S.A.: University of Tennesse Press.

\section{Discography}

Brooks, G. (1993). American Honky-Tonk Bar Association. Capitol Nashville.

Byrd, T. (1998). I'm From the Country. MCA Nashville Records.

Chesney, K. (1999). She Thinks My Tractor's Sexy. BNA Records.

Eminem, Nate Dogg, \& 50 Cent. (2004). Never Enough. Aftermath Entertainment and Interscope Records.

Eminem. (2004). Yellow Brick Road. Aftermath Entertainment and Interscope Records.

Grandmaster Flash, \& the Furious Five. (1982). The Message. Sugar Hill Records.

Haggard, M. (1972). Irma Jackson. Capital Records.

Hobbs, B. (1985). Jones on the Jukebox. MTM Records.

Keith, T. (2002). Courtesy of the Red, White and Blue (The Angry American). DreamWorks Nashville.

Ladacris, \& Nate Dogg. (2001). Area Codes. Def Jam Recordings.

M. O. D. (2003). Wigga. Nuclear Blast Records.

McEntire, R. (2001). I'm a Survivor. MCA Nashville Records.

Nelly. (2000). Country Grammar. Universal Music Group.

Paisely, B. (2011). This is Country Music. Arista Nashville Records.

Queen Latifah. (1993). U.N.I.T.Y. Motown Records.

Reed, J. (1982). She Got the Goldmine and I Got the Shaft. RCA Records.

Russell, J. (1973). Red Necks, White Socks and Blue Ribbon Beer. RCA Records.

Shakur, Tupac (2Pac), \& Dramacydal. (1995). Me Against the World. Interscope Records and Atlantic Records. 
Shakur, Tupac (2Pac), \& Stretch. (1994). God Bless the Dead. Interscope Records and Death Row Records.

Shakur, Tupac (2Pac). (1993). I Get Around. Interscope Records.

Sticky Fingas, \& Eminem. (2001). What if I was White. Universal Records.

Strait, G. (2008). Troubadour. MCA Nashville Recordings.

Sugar Hill Gang. (1979). Rapper's Delight. Sugar Hill Records.

Twitty, C. (1981). Tight Fittin’ Jeans. MCA Nashville Recordings.

\section{Copyrights}

Copyright for this article is retained by the author(s), with first publication rights granted to the journal.

This is an open-access article distributed under the terms and conditions of the Creative Commons Attribution license (http://creativecommons.org/licenses/by/3.0/). 